\title{
DESCONSIDERAÇÃO DA PERSONALIDADE JURÍDICA E ARBITRAGEM: UMA ANÁLISE ACERCA DA EXTENSÃO DA CLÁUSULA COMPROMISSÓRIA A PARTES NÃO SIGNATÁRIAS ${ }^{1}$
}

\author{
DISREGARD OF LEGAL ENTITY AND ARBITRATION: AN ANALYSIS OF THE \\ EXTENSION OF THE ARBITRATION CLAUSE TO NON-SIGNATORY PARTIES
}

João Victor Carloni de Carvalho Mestre em Direito Processual Civil e Bacharel em Direito pela Faculdade de Ciências Humanas e Sociais de Franca UNESP. Membro do Núcleo de Pesquisas Avançadas em Direito Processual Civil brasileiro e comparado (NUPAD UNESP). Advogado e Conciliador. São Paulo/SP. E-mail: carlonijv@gmail.com.

RESUMO: O presente estudo visa analisar a aplicabilidade da desconsideração da personalidade jurídica na arbitragem, a partir das teorias existentes a respeito da extensão da cláusula compromissória a partes não signatárias. Ao contrário do pregado por parte da doutrina e pelo STJ, acredita-se não ser possível a utilização das teorias do implied consent e group of companies, para fins de se justificar a possibilidade de desconstituir o princípio da separação patrimonial em procedimento arbitral.

PALAVRAS-CHAVE: Desconsideração da personalidade jurídica. Arbitragem. Cláusula compromissória. Autonomia da vontade. Procedimento arbitral.

ABSTRACT: This study aims to analyze the applicability of the disregard of legal entity in arbitration, based on theories regarding the extension of the arbitration clause to nonsignatory parties. Instead of the part of the doctrine's and the Brazilian's Superior Court (STJ) positions, it is believed that it is not possible to use the theories of implied consent

\footnotetext{
${ }^{1}$ Artigo recebido em 19/12/2019 e aprovado em 04/03/2020.
} 
and group of companies, in order to justify the possibility of disregarding the principle of patrimonial separation in an arbitral proceeding.

KEY WORDS: Lifting of corporate veil. Arbitration. Arbitration clause. Autonomy of will. Arbitration procedure.

\section{Introdução}

O tema da desconsideração da personalidade jurídica e sua relação com a arbitragem é bastante polêmico e tem ganhado destaque nos estudos atinentes ao procedimento arbitral. Tem-se, cada vez mais, relativizado a questão da vinculação da cláusula compromissória somente àqueles que concordaram com os termos, de maneira expressa, o que se depreende de estudos nacionais e internacionais a respeito do tema. $\mathrm{O}$ presente trabalho possui o escopo, dessa forma, de analisar a questão sob a ótica da chamada extensão dos efeitos da cláusula compromissória a terceiros não signatários do compromisso arbitral.

Para tanto, dividiu-se o trabalho em quatro tópicos.

No primeiro, será abordada a teoria da desconsideração da personalidade jurídica e sua presença e manifestação no direito brasileiro, estabelecendo as diretrizes de sua aplicação, bem como trazendo as relevantes modificações que sobrevieram com a "Lei da Liberdade Econômica" (Lei 13.874/2019) a respeito de definição e parâmetros do instituto.

Num segundo momento, será feito um breve estudo a respeito da cláusula compromissória e suas características, frisando-se a autonomia que possui em relação ao contrato em que se encontra inserida, além da regra de vinculação dos sujeitos ao seu teor, mediante manifestação expressa da autonomia da vontade dos litigantes.

Em seguida, serão estudadas hipóteses em que se tem permitido a extensão dos efeitos da cláusula compromissória a determinados sujeitos que não a tenham assinado expressamente, principalmente no tocante às teorias do grupo de sociedades; consentimento tácito (implícito); e contratos conexos.

No último tópico, será analisada a aplicação da teoria do disregard em matéria de arbitragem, fazendo-se uma comparação com o instituto da extensão da cláusula 
compromissória, vez que parcela da doutrina, e entendimentos jurisprudenciais, tem utilizado de base a teoria dos grupos societários e do consentimento implícito como parâmetros para se aplicar a desconsideração, mesmo que o terceiro atingido pela quebra patrimonial não tenha aquiescido com a solução arbitral do litígio.

A metodologia a ser utilizada será, portanto, dedutiva (partindo-se de diversas premissas para se chegar a conclusões ou ponderações finais), e baseada em materiais bibliográficos, consistindo-se na análise de julgados, doutrinas e das respectivas legislações e comandos legais pertinentes ao tema.

\section{A teoria da desconsideração da personalidade jurídica e sua manifestação no direito brasileiro}

Primeiramente, para que se possa chegar a um entendimento do instituto, necessária uma breve colocação a respeito das justificativas que levaram à concessão da personalidade jurídica a um ente privado, formado por um conglomerado de pessoas físicas que visam explorar uma atividade econômica. Cediço que essa exploração, por si só, é permeada de riscos, os quais podem atingir, não só a pessoa do participante, mas também o seu patrimônio; criou-se, ao longo dos séculos, um mecanismo de separação patrimonial entre os sujeitos integrantes do negócio e a atividade explorada. ${ }^{2}$

Um ente dotado de personalidade e responsabilidade próprias, diferentes das pessoas físicas por trás de seu manejo, permite aos interessados se aventurarem pelas atividades mercantis sem o receio de que terão seu patrimônio jurídico pessoal afetado. Nesse sentido, o que for parte do patrimônio jurídico (inclusos direitos e obrigações) da

\footnotetext{
2 Para o autor Marçal Justen Filho, há dúvidas se o conceito de personalidade jurídica tenha alguma correlação com o direito romano. "Retomado na Idade Média, a partir do trabalho de Sinibaldo de Fleshi (depois Papa Inocêncio IV), a construção dogmática atingiu contornos mais ou menos definidos, com a concepção de que a pessoa jurídica era persona ficta. Tal significava, segundo a grande maioria da doutrina atual, entendimento totalmente diverso daquele posteriormente consagrado por Savigni. A ficção deste não é a ficção dos canonistas e glosadores. Para estes, a fictio significava a criação da mente humana (ou a existência no mundo das ideias); já para os ficcionistas do século XIX, a fictio da pessoa jurídica estava na sua 'falsidade'". In JUSTEN FILHO, Marçal. Desconsideração da personalidade societária no direito brasileiro. São Paulo: RT, 1987, p. 18.
} 
empresa, em tese, não será confundido com o patrimônio pessoal dos indivíduos que a compõem. ${ }^{3}$

Ainda assim, ao se levar a cabo a autonomia patrimonial referente ao direito societário, abre-se espaço para que se utilize a personalidade jurídica com intuito de cometimento de fraudes. Isso porque o ilícito perpetrado pelo componente da empresa em muitas vezes, o próprio administrador - permanece oculto pela conduta aparentemente proba e íntegra da pessoa jurídica. ${ }^{4}$ A teoria da desconsideração da personalidade jurídica também denominada "levantamento do véu corporativo" (lifting of the corporate veil) -, surge, dessa forma, com a finalidade de combater abusos que possam ser perpetrados pelo uso ilegal do instituto da separação patrimonial. ${ }^{5}$

Costuma-se dizer que o caso emblemático de aplicação do instituto foi o Salomon v. Salomon \& Co., no qual o comerciante Aron Salomon, fabricante de botas na Inglaterra do século XIX, constituiu, em 1892, uma sociedade por ações de responsabilidade limitada. ${ }^{6}$ Ele, a esposa, e os cinco filhos do casal, subscreveram capital, sendo que Aron, administrador da companhia, integralizou seu capital social com o próprio negócio de que era proprietário individual, recebendo, inclusive, alguns títulos como dívida dessa nova sociedade constituída. ${ }^{7}$

O governo britânico, principal cliente da companhia, passou a diversificar seus fornecedores de botas de couro, o que ocasionou um excedente nos estoques da empresa, impossibilitada de dar vazão à produção. A sociedade passou a ter dificuldades financeiras, até se tornar insolvente. Questionava-se, desse modo, a responsabilização de Aron Salomon pelo pagamento das dívidas da sociedade, pois, em tese, teria abusado do instituto

\footnotetext{
${ }^{3}$ COELHO, Fábio Ulhôa. Curso de direito comercial, v.2: direito de empresa. 18. Ed. São Paulo: Saraiva, 2014, p. 32.

${ }^{4}$ É o caso, v.g., da empresa que permanece ativa, mas transfere todos seus bens para o patrimônio pessoal dos sócios, com a finalidade de inadimplir determinada obrigação.

5 CARVALHO, João Victor Carloni de; COSTA, Yvete Flávio da. Desconsideração inversa da personalidade jurídica: aplicabilidade no direito de família e aspectos processuais segundo o Novo CPC. In: Maria Amália de Figueiredo Pereira Alvarenga. (org.). Os Novos Paradigmas do Direito de Família e as Políticas Públicas. 1ed. Franca: Cultura Acadêmica, 2017, p. 208.

${ }^{6}$ Cf. GALDINO, Valéria Silva. A aplicabilidade do instituto do disregard no direito de família. Revista Jurídica Cesumar. Vol. 4, $\quad \mathrm{N}^{\mathrm{o}}$ 1, $2004 . \quad$ Disponível em: <http://periodicos.unicesumar.edu.br/index.php/revjuridica/article/view/366/430>. Acesso em: 10 out. 2019; e SARAI, Leandro. Disregard doctrine e sua aplicação pela Administração Pública. Revista de Direito Administrativo \& Constitucional. Belo Horizonte: Fórum, 2003, p. 195.

7 ARAGÃO, Leandro; DIDIER JÚNIOR, Fredie. A desconsideração da personalidade jurídica no processo arbitral. In PEREIRA, Guilherme Setoguti J.; YARSHEL, Flávio Luiz (coord). Processo societário. São Paulo: Quarter Latin, 2012, p. 259.
} 
da separação patrimonial. "As decisões iniciais consideraram que era possível estender a responsabilidade para Aron Salomon, já que ele teria abusado dos privilégios da constituição da sociedade (autonomia da pessoa jurídica) e da responsabilidade limitada. A sociedade seria um 'artifício para fraudar credores", 8

Entretanto, quando a matéria chegou à Câmara dos Lordes (House of Lords) ${ }^{9}$, o julgamento foi revertido em favor de Aron, prestigiando-se, em verdade, a teoria da personalidade jurídica - e sua separação patrimonial -; além da limitação da responsabilidade societária. Em razão disso, parte da doutrina afirma que, na verdade, a origem da desconsideração não se atrela ao uso abusivo da personalidade, mas sim como instrumento hábil a elidir a limitação da responsabilidade em determinados contextos. ${ }^{10}$

Já na doutrina brasileira, a desconsideração da personalidade jurídica é tida como cura ao uso disfuncional da pessoa jurídica, valendo-se, por vezes, da função social da propriedade como fundamento para a desconsideração. É como se o controladoradministrador possuísse um poder-dever de dirigir o negócio visando os interesses da coletividade e evitar o seu mau uso, sendo a personalidade jurídica uma manifestação do direito de propriedade, devendo observar, portanto, a sua função social. ${ }^{11}$ Neste aspecto, lecionam Bertoldi e Ribeiro:

Não se pretende a anulação da pessoa jurídica, mas tão somente afastá-la em situações-limite, onde comprovada sua utilização em desconformidade com o ordenamento jurídico e mediante fraude [...] Se a regra geral é a total separação e autonomia de patrimônios dos sócios em relação à sociedade, sensíveis à crescente utilização fraudulenta da personalidade jurídica por aqueles que, sob o pretexto dessa autonomia e buscando proteção legal, opõem o obstáculo da pessoa jurídica como forma de inviabilizar a devida reparação de danos causados a terceiros,

\footnotetext{
${ }^{8}$ Ibidem, p. 259.

${ }^{9}$ Até a Reforma Constitcuional britânica, a House of Lords era responsável por, além de exercer funções legislativas, julgar a maioria dos recursos em última instância, função esta que passou a ser exercida pela Suprema Corte do Reino Unido. Cf. 〈https://www.parliament.uk/about/how/sovereignty/>. Acesso em 10 out 2019.

${ }^{10}$ Nesse sentido, Cf. WARDE JÚNIOR, Walfrido. Responsabilidade dos sócios. Belo Horizonte: Del Rey, 2007, passim.

11 COMPARATO, Fábio Konder. Função social da propriedade de bens de produção. Direito Empresarial. São Paulo: Saraiva. 1995, p. 34; Cf. também GUIMARÃES, Flávia Lefévre. A desconsideração da personalidade jurídica no Código de Defesa do Consumidor - Aspectos processuais. São Paulo: Max Limonad. 1998, p. 24.
} 
criaram-se normas que excepcionam esse princípio e implementam a teoria da desconsideração da personalidade jurídica no direito pátrio ${ }^{12}$

Nesse sentido, como pressuposto para se afastar o primado da autonomia patrimonial, elege a teoria da desconsideração o uso abusivo ou fraudulento da personalidade. É a chamada formulação subjetiva da teoria, dando destaque ao comportamento do administrador ou sócio em frustrar interesse legítimo de credores. A doutrina brasileira adota, portanto, o instituto da desconsideração da personalidade jurídica como sanção aplicada ao ato ilícito, consistente no desvio de finalidade do uso da personalidade jurídica da empresa.

Nem se diga que referida formulação onera em demasia o demandante em comprovar as intenções fraudulentas do demandado (sócio ou administrador), o que deu azo para o surgimento de premissas que embasassem a formulação da teoria objetiva. ${ }^{13}$

Isso porque o cerne da desconsideração, na denominada teoria objetiva, encontrase, predominantemente, na confusão patrimonial, o que, em tese, facilita a tutela de direitos e interesses dos credores, ou terceiros lesados. "Dessa forma, se há, mediante comprovação documental (v.g escrituração contábil, movimentação de depósitos bancários, etc.), de que a sociedade tem pagado dívidas do sócio, ou este tem recebido créditos pessoais por meio dela, inexiste a diferenciação patrimonial entre as pessoas [jurídica e física]". ${ }^{14}$ Entretanto, deve-se repisar que não apenas mediante confusão patrimonial é que se perpetuarão as aludidas fraudes, motivo pelo qual os requisitos estabelecidos pelo legislador, como se verá, são alternativos, e não cumulativos (coíbe-se tanto o desvio de finalidade, quanto a confusão patrimonial).

A primeira impressão legislativa sobre o tema apareceu no art. 28 do CDC (Lei 8.078/1990), dispondo sobre a possibilidade de se quebrar a autonomia patrimonial quando houver abuso do instituto em detrimento do consumidor, inclusive quando for usada para embaraçar o ressarcimento de danos causados aos consumidores. Posteriormente, outros dispositivos passaram a descrever a matéria, tais como a legislação penal ambiental permitindo a desconsideração no tocante à prática de crimes ambientais -, e também a

\footnotetext{
${ }^{12}$ BERTOLDI, Marcelo M.; RIBEIRO, Marcia Carla Pereira. Curso avançado de direito comercial. 4 ed. ver., atual. e ampl. São Paulo: RT, 2008, p. 150-151.

${ }^{13}$ COELHO, Fábio Ulhoa, op. cit, p. 66.

${ }^{14}$ CARVALHO, João Victor Carloni de; COSTA, Yvete Flávio, op. cit, p. 208-209.
} 
primeira legislação antitruste (Lei no 8.884/1994). Já no Código Civil de 2002, na redação original de seu art. 50, havia a possibilidade de se estender os efeitos de determinadas obrigações aos bens particulares dos administradores ou sócios, nos casos em que caracterizado desvio de finalidade ou confusão patrimonial. ${ }^{15}$

Interessantes modificações sobrevieram com a Medida Provisória nº 881 de 2019 (convertida na Lei 13.874/2019), a qual alterou a supramencionada redação, para incluir ao final que somente será possível aplicar o instituto quando o abuso beneficiar, de forma direta ou indireta, o sócio ou administrador. ${ }^{16}$ Neste ponto, o professor Flávio Tartuce defende a inovação legislativa, justificando que ela impede a aplicação desmedida da desconsideração para fins de atingir pessoa natural que não tenha participado da prática do ato considerado abusivo. ${ }^{17}$

A novel legislação foi responsável, ainda, por incluir em seu $\S 1^{\circ}$ uma definição do que seria desvio de finalidade, classificando-o como a "utilização da pessoa jurídica com o propósito de lesar credores e para a prática de atos ilícitos de qualquer natureza". ${ }^{18}$ Já o $\S 2^{\circ}$ traz que a confusão patrimonial é a ausência de separação de fato entre os patrimônios [pessoal dos sócios e da pessoa jurídica em si], quando houver: "I cumprimento repetitivo pela sociedade de obrigações do sócio ou do administrador ou vice-versa; II - transferência de ativos ou de passivos sem efetivas contraprestações, exceto os de valor proporcionalmente insignificante; e III - outros atos de descumprimento da autonomia patrimonial". Critica-se a inserção do termo "repetitivo", vez que a confusão patrimonial pode ser caracterizada por um ato único de cumprimento obrigacional, hábil a esvaziar o patrimônio e prejudicar credores, por exemplo, utilizar-se o patrimônio jurídico da companhia para saldar dívida imobiliária astronômica do sócio.

\footnotetext{
${ }^{15}$ Ibidem.

${ }^{16}$ Art. 50 do CC/2022. "Em caso de abuso da personalidade jurídica, caracterizado pelo desvio de finalidade ou pela confusão patrimonial, pode o juiz, a requerimento da parte, ou do Ministério Público quando lhe couber intervir no processo, desconsiderá-la para que os efeitos de certas e determinadas relações de obrigações sejam estendidos aos bens particulares de administradores ou de sócios da pessoa jurídica beneficiados direta ou indiretamente pelo abuso".

17 TARTUCE, Flávio. A MP 881/19 (liberdade econômica) e as alterações do Código Civil. Primeira parte. Portal Migalhas. Disponível em <https://www.migalhas.com.br/dePeso/16,MI301612,41046A+MP+88119+liberdade+economica+e+as+alteracoes+do+Codigo+Civil>. Acesso em 10 out. 2019.

${ }_{18} \mathrm{Na}$ redação original da MP 881/2019, havia a necessidade de caracterização de conduta dolosa para configuração do desvio de finalidade, o que foi muito criticado pela doutrina e considerado um retrocesso para fins de aplicação do instituto. Acertadamente, o Congresso Nacional suprimiu o termo, possibilitando a prática da conduta em sua forma culposa.
} 
Já outra inovação que merece ser celebrada é a codificação expressa da chamada desconsideração inversa da personalidade jurídica, presente agora no $\S 3^{\circ}$ do dispositivo ora em lume: "O disposto no caput e nos $\S \S 1^{\circ}$ e $2^{\circ}$ deste artigo também se aplica à extensão das obrigações de sócios ou de administradores à pessoa jurídica”.

Tal modalidade já vinha sendo admitida pela doutrina e jurisprudência pátrias, e possuía menção - embora não estivesse presente, expressamente, a conceituação e seus requisitos na lei - no CPC/2015, em seu art. $133, \S 2^{\circ}{ }^{19}$ Traduz-se no uso fraudulento para desvio de bens da pessoa física para a pessoa jurídica, ou seja, o sócio ou administrador oculta seu patrimônio pessoal ou utiliza-se da personalidade da empresa para se escusar do cumprimento de suas obrigações pessoais.

Dessa forma, os credores não conseguem expropriar o patrimônio do devedor, pois oculto sob o manto da propriedade da empresa. ${ }^{20}$ Trata-se de prática muito comum em lides de cunho familiar, em que o cônjuge ou alimentante, a fim de: escapar da partilha ideal dos bens; minorar o quantum relativo à fixação dos alimentos; ou ainda, frustrar a execução destes, esconde o seu patrimônio sob o manto da aparente separação patrimonial. $^{21}$

Já o $§ 4^{\circ}$ positiva o que já era entendimento do Enunciado 406 da V Jornada de Direito Civil do Conselho de Justiça Federal (CJF), preceituando que a simples existência de grupo econômico não autoriza a aplicação do instituto, devendo-se comprovar a presença dos requisitos do caput do art. 50, CC/2002.

Por fim, o $\S 5^{\circ}$ traz que não será considerado desvio de finalidade a expansão ou alteração da finalidade original da atividade econômica específica da pessoa jurídica. Parcela da doutrina critica a inserção desta norma, pois dificulta o reconhecimento de

\footnotetext{
19 “Aplica-se o disposto neste Capítulo à hipótese de desconsideração inversa da personalidade jurídica".

${ }^{20}$ Nos ensinamentos de Fábio Ulhoa Coelho: "Desconsideração inversa é o afastamento do princípio da autonomia patrimonial da pessoa jurídica para responsabilizar a sociedade por obrigação do sócio" in COELHO, Fábio Ulhoa, op. cit., p. 68.

21 "Não raro, pressentindo o cônjuge ou companheiro a falência do relacionamento, aproveita-se para registrar bens móveis e imóveis em nome da empresa em qual participa. Furtivo o sócio, à sombra do véu da pessoa jurídica, infortuna o patrimônio conjugal, ou resiste às obrigações alimentares. Por vezes, ocorre até a retirada fictícia do sócio da sociedade. Ele, em conluio com terceiro, vende sua parte na empresa, a fim de afastar da partilha as quotas sociais ou o patrimônio do casal que havia sido revertido ao ente societário. Também a dissolução da sociedade, com o mesmo fim de esconder patrimônio partilhável configura abuso da personalidade jurídica. Ainda que a alteração contratual - idealizada para privar o cônjuge ou convivente do exercício de seus direitos sobre os bens comunicáveis - seja perfeita quanto ao seu fundo e à sua forma, mesmo assim o ato é ineficaz com respeito ao consorte lesado" in DIAS, Maria Berenice. Manual de direito das famílias. 11. Ed. Rev. Atual. E ampl. São Paulo: Revista dos Tribunais, 2016, p. 348.
} 
desvio de finalidade, vez que eventual modificação ao objeto-fim do negócio, modifica a própria finalidade original da atividade econômica, muito provavelmente, desviandose de seu propósito originário, e, por vezes, com propósito fraudulento. ${ }^{22}$

\section{Considerações sobre a cláusula compromissória arbitral}

Passa-se, neste momento, à análise da cláusula compromissória arbitral. Longe de esgotar o debate, o que se pretende são apontamentos para fins de, posteriormente, analisar-se a possibilidade de extensão de seus efeitos a terceiros não signatários.

Sem dúvidas, caráter imperativo da arbitragem é a prevalência da autonomia da vontade das partes. Primeiramente, pois é livre e espontâneo o interesse dos litigantes em renunciar à jurisdição estatal para solução do conflito, optando-se pela via arbitral, a qual, dentre outras características, possui maior confidencialidade em relação ao processo público estatal, preservando a imagem dos litigantes - imagem esta que pode vir a sofrer desgaste em razão dos processos judiciais que venha a participar. Em segundo plano, pois a elas (partes) cabe delimitar qual o direito material a ser aplicado, bem como o modo pelo qual se dará o procedimento até a decisão final e pacificação do conflito.

Nesta senda, leciona Carlos Alberto Carmona:

Ponto fundamental da arbitragem é a liberdade dos contratantes ao estabelecer o modo pelo qual o seu litígio será resolvido. Tal liberdade diz respeito ao procedimento a ser adotado pelos árbitros e ao direito material a ser aplicado na solução do litígio, de sorte que o dispositivo legal comentado [art. $2^{\circ}$ da Lei de Arbitragem], ao referir-se no parágrafo primeiro a 'regras de Direito', está-se reportando às regras de forma e de fundo $[\ldots]^{23}$

\footnotetext{
${ }^{22}$ GAGLIANO, Pablo Stolze. A medida provisória da "liberdade econômica" e a desconsideração da personalidade jurídica (Art. 50, CC): primeiras impressões. Disponível em <www.flaviotartuce.adv.br〉. Acesso em: 10 out 2019. No mesmo sentido, leciona Tartuce: "o abuso da personalidade jurídica é algo corriqueiro no Brasil, com o objetivo de prejudicar credores. A par dessa realidade, a MP pode se virar contra os novos empreendedores que procurou valorizar, eis que pequenos e médios empresários poderão ter dificuldades em receber os seus créditos, notadamente frente a empresas maiores que fizeram uso da pessoa jurídica para não arcar com seus compromissos" in TARTUCE, on-line, op. cit.

${ }^{23}$ CARMONA, Carlos Alberto. Arbitragem e processo: um comentário à lei 9.307/96. 3. ed. São Paulo: Atlas, 2009. p. 64.
} 
Vale dizer que a primazia da autonomia da vontade das partes tem sido cada vez mais evidenciada e fomentada em nosso ordenamento processual, inclusive no que tange ao processo civil estatal. Os artigos 190 e 191 do CPC/2015 são provas vivas do estímulo que o legislador tem dado à prevalência da vontade das partes no tocante à condução do processo. Com efeito, é possível às partes, desde que o litígio verse sobre direitos que admitam autocomposição e que os sujeitos sejam plenamente capazes, alterar o procedimento, ajustando-o às particularidades do caso concreto, convencionando a respeito de ônus, poderes, deveres, ou faculdades processuais. ${ }^{24}$

Nos termos da Lei de Arbitragem (Lei n 9.307/1996), a cláusula compromissória arbitral é "a convenção através da qual as partes em um contrato comprometem-se a submeter à arbitragem os litígios que possam vir a surgir, relativamente a tal contrato" (art. $4^{\mathrm{o}}$, caput). Constitui-se, portanto, no compromisso firmado pelas partes, dentro do qual se estabelece que os litígios oriundos daquele negócio jurídico sejam resolvidos mediante procedimento arbitral. Observe-se que, neste caso, o compromisso é predecessor ao litígio, o que não ocorre no chamado compromisso arbitral, caracterizado pela escolha das partes pela jurisdição arbitral após de já instaurado o litígio.

A cláusula compromissória é, dessa forma, negócio jurídico processual bilateral (ou plurilateral) típico, ou seja, consubstancia-se em "ato voluntário, em cujo suporte fático confere-se ao sujeito o poder de escolher a categoria jurídica ou estabelecer, dentro dos limites fixados no próprio ordenamento jurídico, certas situações jurídicas processuais". ${ }^{25}$ Seu caráter bi (ou pluri) lateral, denota que deve ser assentida por duas ou mais partes integrantes do negócio jurídico, e a tipicidade diz respeito à sua expressa previsão legal no ordenamento.

$\mathrm{O} \S 1^{\mathrm{o}}$ do dispositivo em tela preconiza a necessidade de estipulação da cláusula compromissória por escrito, seja no próprio contrato do negócio jurídico, ou em documento referente a ele, mas que se encontre apartado.

Nos dizeres de Ricardo Aprigliano:

\footnotetext{
${ }^{24}$ GAJARDONI, Fernando da Fonseca [et al]. E-book. Teoria geral do processo: comentários ao CPC de 2015 - parte geral. São Paulo: Forense, 2015, passim.

${ }^{25}$ DIDIER JÚNIOR, Fredie, Curso de Direito Processual Civil, 17 Ed., Vol. 1, 2015. Salvador: JusPodivm, p. 376-377.
} 
A exigência da forma escrita é plenamente justificável, na medida em que a escolha da via arbitral importa em renúncia da via estatal, que vem a ser a regra geral em se tratando de solução de conflitos. $\mathrm{E}$, como todo comportamento que importa em renúncia a direitos nunca pode ser presumido nem interpretado de forma ampliada, exige-se manifestação escrita dessa renúncia. ${ }^{26}$

Já o $§ 2^{\circ}$ disciplina que somente haverá eficácia da cláusula compromissória nos contratos de adesão, se houver a iniciativa de instituir o procedimento arbitral, ou houver a concordância expressa de sua instituição, contanto que haja previsão em documento anexo, ou negrito, assinando as partes (ou visto especialmente para a cláusula).

Importante característica da cláusula compromissória é a sua autonomia, o que significa dizer que eventual nulidade do contrato não retira do árbitro a sua competência para dirimir o litígio, regramento presente no art. $8^{\circ}$ da Lei de Arbitragem ${ }^{27}$. O mesmo se aplica no caso de resilição do contrato, não tendo capacidade de revogar, por si só, a validade da cláusula compromissória, vez que esta, uma vez firmada, torna-se defesa de revogação unilateral, dependendo de um acordo de vontades para ser desfeita. ${ }^{28}$

Nesse sentido, não se deve afirmar que é mero ato preparatório para que haja a instituição de arbitragem, mas sim convenção apta, ao menos, a aceitar o juízo arbitral em cabal renúncia à jurisdição estatal - ainda que a legislação pátria denote a instituição da arbitragem somente quando o(s) árbitro(s) aceitar(em) a(s) nomeação(ões) - art. 19, caput da Lei $9.307 / 1996 .^{29}$

\footnotetext{
${ }^{26}$ APRIGLIANO, Ricardo de Carvalho, op. cit, p. 181. Há quem entenda, contudo, que resta superada a formalidade da necessidade da cláusula compromissória se dar estritamente por escrito. "[...] não nos parece que a LA teria o condão de afastar outros meios probatórios da cláusula arbitral, mesmo porque em nenhum momento atribuiu a forma escrita como sendo da substância ou da essencialidade do negócio, conforme técnica legislativa secular brasileira [...] Os legisladores mais atuais já se deram conta de tal situação e gradativamente o requisito formal "por escrito" vem sendo relativizado. Esse é o caso da Lei Modelo da Uncitral depois das emendas adotadas em 2006, na qual o art. $7^{\circ}$ recebeu uma nova opção de redação, na qual o requisito de forma escrita não é contemplado, conforme comentado anteriormente." In HASSON, Felipe; NALIN, Paulo. Existência e validade da cláusula compromissória não escrita: interpretação extensiva do artigo $4^{\circ}, \S 1^{\circ}$, da Lei de Arbitragem, à luz do direito brasileiro e comparado. Revista Brasileira de Arbitragem. Volume XIV. Number 55, 2017, p. 31.

${ }^{27}$ Art. 80: "A cláusula compromissória é autônoma em relação ao contrato em que estiver inserta, de tal sorte que a nulidade deste não implica, necessariamente, a nulidade da cláusula compromissória".

${ }^{28}$ APRIGLIANO, Ricardo de Carvalho, op. cit, p. 179.

29 "A cláusula compromissória não é ato preparatório ou preliminar do compromisso arbitral; por si só, é suficiente para que o árbitro assuma sua função e dê início ao processo arbitral, sem que haja necessidade de qualquer outra providência. O Código de Processo Civil, no artigo 301, IX, acompanha esse entendimento dispondo que a convenção de arbitragem é matéria que o réu deve alegar antes de discutir o mérito, permitindo ao juiz que se afaste do processo (extinção do processo sem julgamento do mérito) diante da
} 
A própria cláusula vazia, presente quando não se encontram elementos suficientes para a instauração da arbitragem (ex: ausência de indicação dos árbitros ou da câmara arbitral; do direito aplicável; ou ainda, quando possui o condão de somente indicar que a solução da questão se dará por arbitragem, de forma genérica); ainda que considerada patológica $^{30}$ e de eficácia limitada, tem capacidade de, ao menos, exercer esse efeito de renúncia.

Vale dizer que, em regra, a cláusula compromissória obriga e vincula apenas as partes contratantes, ou seja, em prevalência ao primado da autonomia da vontade, somente poder ser parte no procedimento arbitral aquele que aquiesceu expressamente com a sua instituição para solucionar a controvérsia. ${ }^{31}$

Contudo, em determinadas situações, pode vir a ocorrer a modificação dos sujeitos participantes da relação jurídica material, levando-se ao questionamento da prevalência da cláusula sobre a pessoa adquirente, sucessora na relação negocial. Apontase para o entendimento de que, havendo transmissão do contrato, transmite-se, também, a cláusula compromissória, partindo-se do pressuposto de que o cessionário assume todos os direitos e deveres oriundos da relação pretérita e que está contraindo. ${ }^{32}$

Mesmo quando não há previsão legal específica, doutrina e jurisprudência (nacional e internacional) vão mais além, e tem permitido a extensão dos efeitos da cláusula compromissória a terceiros não signatários, de forma excepcional e com fixação de certos parâmetros, os quais se abordarão em seguida.

vontade manifestada pelas partes de resolver futuras controvérsias através do julgamento arbitral. Isso demonstra um grande incentivo à arbitragem e à vontade manifestada pelas partes em resolver disputas através deste meio alternativo de solução de litígios” in MOSCHEN, Valesca Raizer Borges; OLIVEIRA, Agatha Brandão de. Os novos paradigmas da arbitragem no âmbito societário: a extensão subjetiva da convenção arbitral. Revista da Faculdade de Direito Milton Campos, v. 24, 2012, p. 356.

${ }^{30}$ CARMONA, Carlos Alberto. op. cit, p. 114.

31 "Se a arbitragem é uma criatura da vontade, apenas aqueles que concordaram em arbitrar determinado litígio ou litígios advindos de uma determinada relação jurídica estarão vinculados à obrigação de não demandar perante o Poder Judiciário a sua composição. Essa é uma realidade que encontra fundamento simultaneamente no direito privado (segundo o princípio da relatividade dos contratos) e no direito público (o direito brasileiro condiciona a renúncia à jurisdição estatal, nos casos em que arbitrável o litígio, à manifestação válida de vontade do envolvido e à possibilidade de controle posterior - irrenunciável - da validade da sentença arbitral pelo Poder Judiciário)" in BENEDUZI, Renato Resende. Desconsideração da personalidade jurídica e arbitragem. Revista de Processo. | vol. 290, Abril, 2019, p. 473-474.

${ }^{32}$ GUERRERO, Luis Fernando. Convenção de arbitragem e processo arbitral. São Paulo: Atlas, 2009, p. 140; Cf. também GOMES, Técio Spínola. A transmissibilidade da cláusula arbitral diante da cessão de posição contratual. Revista de Direito Civil Contemporâneo. vol. 5, Out - Dez, 2015. 


\section{A possibilidade de extensão da cláusula compromissória a parte(s) não signatária(s)}

Nesta etapa do estudo, far-se-á uma análise doutrinária e jurisprudencial a respeito da teoria do group of companies (grupo de sociedades), implied consent (consentimento tácito à arbitrabilidade), e do group of contracts (contratos coligados); todas versando sobre argumentos aptos a mitigar a vinculação da cláusula compromissória somente aos sujeitos processuais subscritores do negócio jurídico, e estender seus efeitos a terceiros não signatários do pacto inicial.

Em termos de estudos internacionais, o considerado leading case a fundamentar os defensores da extensão da cláusula compromissória por caracterização de grupo de sociedades é tido como o Dow Chemical vs. Isover Saitn-Gobain. Após ocorrência de irregularidades com um dos produtos objeto do contrato de distribuição entabulado entre sociedade pertencente ao grupo americano (Dow Chemical) e a sociedade francesa (Isover Saint-Gobain), foi instaurado procedimento arbitral por partes não signatárias da Dow Chemichal - mas pertencentes ao grupo societário americano, inclusive participando, essas partes não signatárias, ativamente da materialização do negócio jurídico, e, também, de contratos de distribuição - e da concretização do contrato originário, apesar da ausência de firma expressa. A sociedade francesa tentou, de plano, arguir a incompetência do tribunal arbitral, tendo em vista que as companhias que deram origem ao procedimento não haviam assinado o contrato cujo conteúdo continha a cláusula compromissória. Contudo, entenderam os árbitros que havia provas suficientes do comportamento das companhias condizentes com aceitação dos termos do contrato original, ainda que não signatárias da cláusula compromissória original.

Equivoca-se quem pensa que referida decisão criou a chamada "teoria do grupo societário", em que, resumidamente, apregoa-se o mero pertencimento ao grupo para haver a extensão dos efeitos. Isso se denota, pois em algumas ocasiões, a extensão acabou sendo rejeitada pela Câmara de Comércio Internacional (CCI 4504/1985; CCI 9873/1999; CCI 9517/2000; 10758/2000; CCI 10818/2001). ${ }^{33}$

\footnotetext{
${ }^{33}$ MELO, Leonardo de Campos. Extensão da cláusula compromissória e grupos de sociedades na CCI (de acordo com o Regulamento CCI-2012). Revista de Arbitragem e Mediação. Ano 10. Vol 36. Jan-mar, 2013, p. 257-262. Cf. também Brekoulakis, Stavros L. Third Parties in International Commercial Arbitration, Oxford: Oxford University Press, 2010.
} 
Também em outros precedentes da CCI (CCI 6519/91; CCI 7604 e 7610/1995; CCI 10510/2000; 5103/1988; CCI 11160/2002), jamais foi utilizado o simples pertencimento ao grupo de sociedades como fundamento para a extensão a partes não signatárias, mas sim a análise do quadro fático-probatório e das relações jurídicas e negociais, chegando-se à conclusão de que, mesmo não havendo concordância expressa firmada mediante subscrição, o comportamento das partes e das empresas é que definiu a aceitação da arbitragem como método de solução do litígio, estendendo-se os efeitos da cláusula. $^{34}$

Já no Brasil, o caso Trelleborg (2006) foi o que ganhou destaque. Neste caso emblemático, a sociedade Anel Empreendimentos, Participações e Agropecuária Ltda (chamada, doravante de Anel) e seu sócio-diretor faziam parte do quadro societário de PAV (Projetos e Aplicações de Vibrotécnica de Vedação Ltda.), cuja finalidade empresarial era dedicada à indústria, comércio e exportação de materiais utilizados em veículos pesados e borracha. Mediante série de acordos e negociações com a empresa sueca Trelleborg Industri AB, constituíram holding do Grupo Trelleborg em parceria com a Trelleborg do Brasil Ltda, chamando-o de Trelleborg PAV Indústria e Comércio Ltda. A controvérsia teve origem após aquisição pela "empresa-mãe" sueca da AVS Brasil Getoflex, sociedade que era a principal concorrente da Anel no Brasil, inviabilizando os negócios da holding PAV. Em razão do ocorrido, a Anel notificou Trelleborg do Brasil Ltda. e Trelleborg Industri $A B$ para fins de dar início a procedimento arbitral visando a dissolução parcial da sociedade, apurando-se perdas e danos e lucros cessantes, consoante disposição de cláusula arbitral inserta no contrato celebrado com Trelleborg do Brasil Ltda. Tendo em vista a recusa das partes em iniciar a arbitragem, foi dado início à ação judicial prevista no art. $7^{\circ}$ da Lei de Arbitragem. ${ }^{35}$ A sueca Trelleborg Industri $A B$ tentou alegar ilegitimidade passiva, contudo permaneceu a tese de que participara ativamente de toda a negociação que ensejou a celebração dos contratos entre os demais sujeitos processuais. ${ }^{36}$ Com efeito, "a interpretação extensiva da cláusula arbitral é perfeitamente

\footnotetext{
${ }^{34}$ Ibidem, p. 264-266.

35 Art. $7^{\circ}$ "Existindo cláusula compromissória e havendo resistência quanto à instituição da arbitragem, poderá a parte interessada requerer a citação da outra parte para comparecer em juízo a fim de lavrar-se o compromisso, designando o juiz audiência especial para tal fim".

${ }^{36}$ FURLAN FILHO, Antonio Moacir. A extensão da cláusula arbitral estatutária aos administradores e conselheiros não acionistas. Revista de Arbitragem e Mediação (Rarb), vol. 49 (abril - junho), 2016, passim.
} 
possível, na medida em que os negócios jurídicos devem ser analisados à luz da boa-fé e seus consectários, a confiança, a lealdade contratual, etc., que, aliás, representam a pedra de toque de todas as relações jurídicas". ${ }^{37}$

Percebe-se, novamente, que para a configuração da extensão foi necessário comportamento ativo da parte nas celebrações e negociações, requisito que se não estivesse cumprido, poderia ensejar o não acolhimento do pedido de instauração de tribunal arbitral. Nesse sentido, crê-se que o elemento a ser observado não é o pertencimento a um grupo societário, de per si - o que afasta a teoria pura do group of companies -, mas sim a conduta dentro das negociações que evidenciem uma concordância, ainda que tácita, com a resolução do litígio pela via arbitral (implied consent).

Acompanhando esse raciocínio, a doutrina internacional traz que: "the effects of the arbitration clause extend to parties directly involved in the performance of the contract, provided that their respective situations and activities raise the presumption that they were aware of the existence and scope of the arbitration clause, so that the arbitrator can consider all economic and legal aspects of the dispute". ${ }^{38}$

Vale dizer que tal entendimento foi recepcionado pelo legislador brasileiro no tocante ao instituo da desconsideração da personalidade jurídica, consoante se denotou nos comentários ao art. 50 do CC/2002 - após as alterações legislativas de 2019 -, em que a mera caracterização de grupo societário não é suficiente para ensejar a desconsideração.

Em relação aos contratos conexos, é inegável sua presença nas práticas comerciais, principalmente internacionais, em que determinado negócio jurídico é firmado mediante contratos diversos, mas que possuem objetos interconectados. Seu conteúdo encontra-se em dependência unilateral ou recíproca aos demais instrumentos firmados, o que autoriza a extensão da cláusula compromissória. "Se a arbitragem é prevista quanto ao contrato principal, não há muitas dúvidas de que as partes se obrigaram a esse método também nos contratos secundários (admitindo que os contratos secundários se refiram ao principal e não contenham, eles próprios, convenção de arbitragem)". 39 É o que se

\footnotetext{
${ }^{37}$ Ibidem.

38 "os efeitos da cláusula compromissória se estendem às partes diretamente envolvidas na execução do contrato, desde que suas respectivas situações e atividades aumentem a presunção de que estavam cientes da existência e do escopo da cláusula compromissória, para que o árbitro possa considerar todos os aspectos econômicos aspectos jurídicos da disputa" (tradução livre) in GAILlARD, E. SAVAGE, J. Fouchard Gaillard Goldman on International Arbitration. Kluwer Law, 1999. p. 428.

${ }^{39}$ APRIGLIANO, Ricardo de Carvalho, op. cit, p. 188.
} 
denomina de "cláusula arbitral por referência", comum nas relações comerciais entabuladas por meio de contratos-tipos das associações profissionais especializadas, como as que atuam nas áreas de algodão, café e cereais em geral. ${ }^{40}$

Forçoso reconhecer, portanto que há situações excepcionais que demandam a superação do efeito vinculante da cláusula compromissória apenas aos signatários, podendo-se transformar terceiros em partes da arbitragem em razão, principalmente, de seu comportamento durante os atos negociais e a própria formulação do contrato, ou do negócio jurídico. Feitas essas considerações, passa-se ao estudo do instituto da desconsideração da personalidade jurídica e sua relação com a arbitragem.

\section{Desconsideração da personalidade jurídica e procedimento arbitral}

A doutrina divide-se quando o assunto é a presença da desconsideração da pessoa jurídica na arbitragem.

Há aqueles que entendem pela sua plena aplicação, utilizando-se, analogicamente, os conceitos de aceitação tácita da cláusula compromissória (e a extensão dos seus efeitos nos contratos societários e por meio do consentimento implícito), além de sua extensão de acordo com a teoria do grupo societário, desde que evidenciada, ou passível de presunção a má-fé do terceiro a que se pretende atingir. ${ }^{41}$ Apoiando-se, sobretudo, na finalidade da desconsideração em coibir o mau uso da personalidade jurídica (seja por desvio de finalidade ou confusão patrimonial), adeptos do emprego do instituto na arbitragem sustentam que não parece razoável permitir escusas à resolução do conflito pela via arbitral. "Além do mais, deve-se considerar que o objetivo da teoria da desconsideração é trazer à lume a parte que, no plano da realidade, contraiu a obrigação, mas que for razões estranhas a ela, decidiu se subtrair do negócio jurídico". ${ }^{42}$

\footnotetext{
${ }^{40}$ FURLAN FILHO, Antonio Moacir, op. cit.

${ }^{41}$ Cf. WALD, Arnoldo. A desconsideração na arbitragem societária. Revista de Arbitragem e Mediação. vol. 44 (jan - mar) 2015; PRADO, Viviane Muller; DECCACHE, Antonio. Arbitragem e desconsideração da pessoa jurídica. In: CONPEDI. (Org.). Direito Empresarial. XXI Congresso Nacional do CONPEDI/UFF. 1ed.Florianópolis: FUNJAB, 2012, p. 216-245, pp. 236-237. Disponível em http://www.publicadireito.com.br/artigos/?cod=f5496252609c43eb;

42 PRADO, Viviane Muller; DECCACHE, Antonio, op. cit.. Nesse sentido, "No domínio da doutrina e das práticas da arbitragem, um último tipo de situação (o quarto, na classificação que estou seguindo) usa ser invocado como fundamento da extensão da eficácia da convenção de arbitragem a pessoas que não a subscreveram. Para quem recuse as doutrinas ditas do grupo de sociedades, da agência ou da presunção da
} 
Com efeito, complementa Arnoldo Wald:

Mais polêmica é a aplicação da cláusula compromissória quando se trata de terceiro que, de má-fé, com abuso de direito ou fraude, utilizou o seu poder de controle para realizar o contrato que ensejou o litígio, ou cedeu o mesmo a terceiro para que o demandado na arbitragem fosse uma espécie de "laranja" insolvente, permitindo que o verdadeiro contratante (do ponto de vista econômico) deixasse de ser o responsável. Nestes casos é que se discute a possibilidade de aplicação da desconsideração, com o caráter de sanção. Trata-se de, havendo má-fé, contornar o princípio essencial e básico no direito comercial da limitação da responsabilidade da empresa para buscar o verdadeiro responsável. ${ }^{43}$

Por outro lado, há quem entenda que, se o terceiro que se visa atingir com a desconsideração, for também, parte integrante da cláusula compromissória, não há qualquer infortúnio em se aplicar o instituto, até porque, neste caso, presente estaria a autonomia da vontade das partes e a aquiescência com o procedimento arbitral. Aplicandose o princípio da competência-competência, o próprio árbitro tem jurisdição para averiguar a responsabilização ou não deste terceiro.

A celeuma surge, obviamente, quando o terceiro não é signatário da convenção. Para os adeptos desta corrente, não há, no direito brasileiro, espaço para que se vincule terceiro sem o seu consentimento, aplicando-lhe a tutela sancionatória presente na teoria do disregard. Como visto anteriormente, nos casos de extensão dos efeitos da convenção a quem não tenha concordado, vale-se da premissa de que tenha havido comportamento evidente no sentido de aceitação da solução do conflito mediante instauração de tribunal arbitral.

aceitação tácita da convenção, esse tipo de situação invade, embora extravasando-o, o campo dos grupos de sociedades. Refiro-me ao stoppel do direito norte-americano, que entre nós pode ser qualificado como abuso de direito, designadamente nas modalidades da inegabilidade formal e do venire contra factum proprium, $\mathrm{e}$ pode levar ao levantamento da personalidade colectiva [...] Demonstrado o abuso de direito, poderá o levantamento da

personalidade colectiva servir também para sujeitar à convenção de arbitragem o sócio que actuou com a máscara da sociedade, ao fazer inserir no contrato por esta assinado a cláusula compromissória? Não me repugna e a solução tem sido aceite no espaço jurídico alemão. Mas repare-se que, se se quiser (e, em minha opinião, deve-se querer) continuar a pisar terreno juridicamente firme, o levantamento da personalidade colectiva poderá conduzir à vinculação do sócio - ou da sociedade-mãe - que atrás da sociedade signatária da convenção se ocultou, mas muito dificilmente chegará à vinculação de outras sociedades do grupo que não sejam sócias da signatária." in FREITAS, José Lebre de. Intervenção de terceiros em processo arbitral. Revista de Processo. vol. 209, 2012, p. 440-441.

${ }^{43}$ WALD, Arnoldo, op. cit., p. 51. 
A decretação do levantamento do véu pressupõe, necessariamente, o acertamento de fatos estranhos aos limites objetivos da cláusula compromissória - de modo a verificar a conduta do terceiro que, abusando do poder de controle, perpetrou injustiça contra o credor, o que também não se admite. Com tudo isso não se quer dizer, obviamente, que não seja possível vincular um terceiro à convenção arbitral mediante o emprego de outras teorias, como a do grupo de sociedades (embora não se trate, a rigor, de uma autêntica extensão). A desconsideração da personalidade jurídica, no entanto, não deve servir de fundamento para essa vinculação em razão de seu caráter essencialmente sancionatório. ${ }^{44}$

Com efeito, apesar de o árbitro ser juiz de fato e de direito, seu poder de decisão esbarra em limites constantes na própria convenção de arbitragem, a qual estabelece, também, os limites da cognição arbitral. Em razão da origem contratual que possui a arbitragem, seus limites de cognição não podem ser ampliados para além do negócio jurídico entabulado. Ademais, o instituto da desconsideração amplia o objeto de litígio para além do negócio jurídico: o desvio de finalidade e a confusão patrimonial, matérias alheias e que sequer foram convencionadas pelas partes, o que fere o brocardo da autonomia da vontade. $^{45}$

Tem-se doutrina internacional a corroborar com essa corrente, verbis: “[...] because of the contractual basis of arbitration, the scope of the arbitration agreement should not be extended to punish the behaviour of a third party. Such measures should only be taken by the courts, before which a party will always be able to argue that the corporate veil should be lifted". ${ }^{46}$

Acredita-se que este último entendimento se coaduna mais com os propósitos de um procedimento arbitral. Isso porque, como analisado no tópico anterior, a extensão dos efeitos a terceiros é medida excepcional e decorre da assunção de que o sujeito participou do negócio jurídico e concordou com a arbitragem, ainda que sem manifestação expressa no firmamento da cláusula compromissória. No caso da sanção decorrente da quebra da autonomia patrimonial, não se tem a mesma situação. ${ }^{47}$

\footnotetext{
${ }^{44}$ BENEDUZI, Renato Resende, op. cit., p. 475-476.

${ }^{45}$ ARAGÃO, Leandro; DIDIER JÚNIOR, Fredie, op. cit., p. 266-267.

46 "Em razão da base contratual da arbitragem, o escopo convenção de arbitragem não deve ser estendido para punir o comportamento de terceiros. Tais medidas devem ser tomadas apenas pelos tribunais, perante os quais uma parte sempre poderá argumentar que o véu corporativo deve ser levantado" (tradução livre) in FOUCHARD; GAILLARD; GOLDMAN. On international commercial arbitration. 1999. p. 284.

47 "A etiologia de ambos os institutos também revela a marcante diferença que os distingue, tendo em vista que, enquanto a desconsideração da personalidade jurídica decorre da lei ou do princípio geral que veda a
} 
Permite-se, todavia, após findo o procedimento arbitral, que durante a execução do título executivo formado (sentença arbitral) invoque-se a desconsideração da personalidade jurídica, momento em que o terceiro alheio poderá ser convocado a integrar a lide e se defender, exercendo contraditório efetivo. ${ }^{48}$

O STJ, entretanto, optou por acatar a tese de possibilidade de instauração do incidente de desconsideração da personalidade jurídica na arbitragem, tese fixada no julgamento do REsp 1.698.730/SP. No referido processo, houve celebração de contrato de prestação de serviços e obras de engenharia firmado entre a tomadora Continental do Brasil Produtos Automotivos Ltda e Serpal Engenharia e Construção Ltda (prestadora de serviços), no qual se tinha como objeto expansão de uma fábrica de pneus no Município de Camaçari/BA. Devido a atrasos nas obras e dificuldades financeiras da prestadora, declarou-se a resolução do contrato, cobrando-se a quantia de cem milhões de reais em procedimento instaurado perante o Centro de Arbitragem da Câmara de Comércio BrasilCanadá $(\mathrm{CCBC}){ }^{49}$

Apurou-se o desvio de finalidade mediante operações societárias entre a Serpal e um sujeito controlador de 04 (quatro) “empresas de prateleira” entre 2010 e 2013, alterando-se o controle desta companhia até a dilapidação de se patrimônio em off-shores estabelecidas no exterior em nome do controlador (Juan Queiroz) e de seus familiares, "blindando" as dívidas. A empresa Continental ingressou, então, com pedido cautelar de arresto de imóveis e declaração da desconsideração da personalidade jurídica da Serpal, sendo deferido pela primeira e segunda instância. Os requeridos recorreram ao STJ, alegando ausência de prestação de caução e não propositura da ação principal; ausência de preenchimento de requisitos para a medida cautelar; inexistência de requisitos para a desconsideração.

Nos termos do voto-vencido da Ministra Nancy Andrighi, primeiramente não havia que se discutir a desconsideração, pois era questão de fato, e não de direito. Em

prática de ato contrário ao direito, a extensão da convenção arbitral decorre da própria vontade das partes signatárias e não signatárias, manifestada por seu comportamento e identificada por elementos de prova apresentados na arbitragem" in MELO, Leonardo de Campos, op. cit, p. 267.

48 Nesse sentido, Carmona: “caberá ao juiz togado (e não ao árbitro) tomar eventuais medidas para estender os efeitos da sentença arbitral” in CARMONA, Carlos Alberto, op. cit., p. 83. Para aprofundamento na utilização da desconsideração após "judicialização" da sentença arbitral, Cf. BENEDUZI, Renato Resende, op. cit.

${ }^{49}$ STJ, REsp 1698730/SP, Rel. Ministro MARCO AURÉLIO BELLIZZE, TERCEIRA TURMA, julgado em 08/05/2018, DJe 21/05/2018. 
seguida, prestou-se a dizer que em razão do incidente de desconsideração da pessoa jurídica afetar direito de terceiros, não caberia ao Tribunal Arbitral reapreciar decisão feita pela Justiça Estadual. Argumentou, ainda, que deve prevalecer o princípio fundamental da autonomia da vontade, somente obrigando as partes que celebraram a convenção a comparecer perante o tribunal arbitral; além da aplicação do kompetenz-kompetenz, em que o próprio juízo arbitral possui competência para se manifestar, sendo que "os árbitros expressamente reconheceram a sua incompetência para a reapreciação da medida cautelar, por envolver terceiros alheios à convenção arbitral, bem como a necessidade de coexistência, nessa situação específica, das decisões estatais e arbitrais". ${ }^{50}$

O voto vencedor foi o do próprio relator, Marco Aurélio Belizze, dissertando que era dever do juízo arbitral confirmar a tutela provisória e precária concedida em juízo estatal; que a questão da desconsideração da personalidade jurídica deveria ter sido arguida na ação principal, perante a jurisdição arbitral, de modo que os efeitos subjetivos da sentença pudessem atingir os desconsiderados e estes pudessem exercer o contraditório pleno e efetivo; que a cautelar possuía propósito de assegurar o resultado útil da arbitragem, devendo ser submetida ao juízo arbitral. Argumentou, ainda, que nestes casos conta-se com um consentimento tácito à instituição do tribunal arbitral, vez que "caso prevaleça o entendimento de que a convenção produz efeitos apenas às partes signatárias, o processo arbitral servirá de escudo para evitar a responsabilização do terceiro que laborou em fraude". Dessa forma, o abuso da personalidade jurídica e a má-fé indicariam a existência de consentimento implícito (implied consent) do terceiro em relação à arbitragem. ${ }^{51}$

Discorda-se do posicionamento adotado pela Corte, como bem delineado acima, pois a imputação de responsabilidade, seja solidária, seja de qualquer natureza, a quem não tenha participado da celebração da convenção de arbitragem - ou da celebração do negócio jurídico como um todo - não parece ser matéria que possa ser dirimida por tribunal arbitral, vez que significaria transbordar limites estabelecidos pelo próprio negócio jurídico que deu origem à arbitragem, violando-se a autonomia da vontade das partes. ${ }^{52}$

\footnotetext{
${ }^{50}$ Ibidem.

${ }^{51}$ Ibidem.

${ }^{52}$ ARAGÃO, Leandro; DIDIER JÚNIOR, Fredie, op. cit., p. 266-267.
} 
Por óbvio que não se pretende a "impunidade" daquele que se utiliza do primado da separação patrimonial com fins obscuros e ilícitos (inclusive no tocante à instauração do procedimento arbitral). Todavia, acredita-se mais plausível a resolução do impasse mediante atuação judicial, donde o sujeito acusado de desviar a finalidade da empresa, ou confundir o patrimônio jurídico da entidade societária com o pessoal, poderá utilizar os instrumentos necessários à plena efetivação do contraditório - contraditório este, que não pôde ser exercido na arbitragem, em razão da sua não condescendência com a solução arbitral.

Isso porque, consoante denota o regulamento processual do incidente de desconsideração da personalidade jurídica (art. 133 a 135 c.c art. 916, VI do CPC/2015), quando o incidente for requerido na petição inicial - incluindo, aqui, a tutela executiva de sentença arbitral -, poderá o citado se utilizar de toda e qualquer matéria de defesa e concentrá-la numa única petição. ${ }^{53} \mathrm{E}$, nos casos em que o pedido de desconsideração for feito de forma incidental, poderá o citado se defender, também, via petição simples. ${ }^{54}$

\section{Conclusão}

Evidente que, em determinados casos, o princípio da separação patrimonial que permeia o direito empresarial merece ser superado mediante aplicação da desconsideração da personalidade jurídica, seja em razão de se quebrar a limitação de responsabilidade, seja com o intuito de coibir o uso fraudulento da pessoa jurídica para prejudicar credores. De acordo com a sua manifestação no direito brasileiro, a doutrina costuma caracterizar a desconsideração como sendo uma sanção ao desvio de finalidade ou à confusão patrimonial da persona jurídica, propiciando ao lesado a devida reparação.

Antes de adentrar ao campo da sua aplicação na arbitragem, foi necessária uma breve explanação a respeito das particularidades que circundam a cláusula compromissória, principalmente no tocante ao seu caráter autônomo em relação ao contrato em que está inserta - o que permite com que o intuito em resolver a lide oriunda

\footnotetext{
${ }^{53}$ Este, inclusive, é o Enunciado n. ${ }^{\text {o }} 248$ do Fórum Permanente de Processualistas Civis (FPPC): "Quando a desconsideração da personalidade jurídica for requerida na petição inicial, incumbe ao sócio ou a pessoa jurídica, na contestação, impugnar não somente a própria desconsideração, mas também os demais pontos da causa"

${ }^{54}$ CARVALHO, João Victor Carloni de; COSTA, Yvete Flávio da, op. cit, 2017, p. 214.
} 
do contrato por meio da arbitragem seja transmitido para os futuros sujeitos que passem a vigorar no negócio jurídico. Outra característica importante é a necessidade de consentimento da parte, devendo, via de regra, assinar o contrato escrito cujo teor contenha a cláusula compromissória, a fim de se externalizar a vontade em solucionar o conflito pelas vias arbitrais.

Ocorre que doutrina e jurisprudência tem apontado para situações em que se é possível estender os efeitos da cláusula compromissória a terceiros não signatários, em hipóteses excepcionais, é claro. Como salientado, deve-se analisar o comportamento subjetivo das partes durante todas as etapas da negociação, extraindo do conjunto fáticoprobatório se houve consentimento - ainda que tácito - em relação à instauração de juízo arbitral. Desse modo, não basta a mera caracterização de grupo de sociedades para atingir não signatário.

No que tange à aplicação da teoria da desconsideração da personalidade jurídica nos procedimentos arbitrais, também há latente divergência de opiniões entre aqueles que entendem ser possível a sua plena incidência, vez que, cada vez mais se tem observado a extensão dos efeitos da cláusula compromissória a quem não tenha sido parte no negócio; e aqueles que pugnam pela incongruência entre a autonomia da vontade - primado corolário do procedimento arbitral - e a tutela-sanção preconizada pelo instituto da desconsideração da personalidade jurídica.

Nesse sentido, o STJ adotou posição favorável à utilização da técnica do lifiting of corporate veil em procedimentos que envolvam arbitragem, argumentando que a jurisdição arbitral não deve ser utilizada como escudo, blindagem, para cometimento de fraudes. No entendimento da Corte, comprovada a má-fé e a utilização fraudulenta do uso do instituto da pessoa jurídica caracterizar-se-ia um consentimento implícito com a solução do litígio mediante via arbitral, em analogia à possibilidade de extensão dos efeitos da cláusula ao terceiro não signatário.

Salvo melhor juízo, entende-se equivocada referida interpretação. A uma, pois a desconsideração em nada se confunde com a extensão dos efeitos a terceiros não signatários, esta decorrente do primado da autonomia da vontade e prevalência do comportamento dos sujeitos processuais, e aquela decorrente de previsão legal (art. 50 do CC/2002) ou principiológica. Ademais, implicar-se-ia em ampliação extensiva do objeto 
do litígio a algo não pactuado entre os litigantes, englobando-se as matérias do desvio de finalidade ou da confusão patrimonial, que podem sequer terem sido objeto de deliberação e consentimento entre os interessados.

Ainda que se traduza em "judicialização" da arbitragem, parece mais correto aguardar-se a execução da sentença arbitral para requerer o incidente de desconsideração, propiciando ao suposto agente fraudulento a oportunidade de exercer o pleno contraditório, tendo em vista a ausência de sua vontade (ainda que implícita) pela decisão via procedimento arbitral.

\section{REFERÊNCIAS}

APRIGLIANO, Ricardo de Carvalho. Cláusula compromissória: aspectos contratuais. Revista do Advogado, v. 116, 2012, p. 174-192.

ARAGÃO, Leandro; DIDIER JÚNIOR, Fredie. A desconsideração da personalidade jurídica no processo arbitral. In PEREIRA, Guilherme Setoguti J.; YARSHEL, Flávio Luiz (coord). Processo societário. São Paulo: Quarter Latin, 2012, p. 255268.

BENEDUZI, Renato Resende. Desconsideração da personalidade jurídica e arbitragem. Revista de Processo. vol. 290, Abril, 2019, p. 473-492.

BERTOLDI, Marcelo M.; RIBEIRO, Marcia Carla Pereira. Curso avançado de direito comercial. 4 ed. ver., atual. e ampl. São Paulo: RT, 2008.

CARMONA, Carlos Alberto. Arbitragem e processo: um comentário à lei 9.307/96. 3. ed. São Paulo: Atlas, 2009.

CARVALHO, João Victor Carloni de; COSTA, Yvete Flávio da. Desconsideração inversa da personalidade jurídica: aplicabilidade no direito de família e aspectos processuais segundo o Novo CPC. In: Maria Amália de Figueiredo Pereira Alvarenga. (org.). Os Novos Paradigmas do Direito de Família e as Políticas Públicas. 1ed. Franca: Cultura Acadêmica, 2017, p. 204-219.

CARVALHOSA, Modesto. Comentários à lei das sociedades anônimas. São Paulo: Saraiva, 1997 
COELHO, Fábio Ulhôa. Curso de direito comercial, v.2: direito de empresa. 18. Ed. São Paulo: Saraiva, 2014.

COMPARATO, Fábio Konder. Função social da propriedade de bens de produção.

Direito Empresarial. São Paulo: Saraiva. 1995.

DIAS, Maria Berenice. Manual de direito das famílias. 11. Ed. Rev. Atual. E ampl. São Paulo: Revista dos Tribunais, 2016.

FOUCHARD; GAILLARD; GOLDMAN. On international commercial arbitration. 1999.

FREITAS, José Lebre de. Intervenção de terceiros em processo arbitral. Revista de Processo. vol. 209, 2012.

FURLAN FILHO, Antonio Moacir. A extensão da cláusula arbitral estatutária aos administradores e conselheiros não acionistas. Revista de Arbitragem e Mediação (Rarb), vol. 49 (abril - junho), 2016.

GAGLIANO, Pablo Stolze. A medida provisória da "liberdade econômica" e a desconsideração da personalidade jurídica (Art. 50, CC): primeiras impressões.

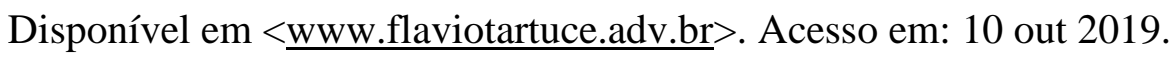

GAILlARD, E. SAVAGE, J. Fouchard Gaillard Goldman on International Arbitration. Kluwer Law, 1999.

GALDINO, Valéria Silva. A aplicabilidade do instituto do disregard no direito de família. Revista Jurídica Cesumar. Vol. 4, $\mathrm{N}^{\mathrm{o}}$ 1, 2004. Disponível em: <http://periodicos.unicesumar.edu.br/index.php/revjuridica/article/view/366/430>. Acesso em: 10 out. 2019.

GOMES, Técio Spínola. A transmissibilidade da cláusula arbitral diante da cessão de posição contratual. Revista de Direito Civil Contemporâneo. vol. 5, Out - Dez, 2015, p. 69-81.

GUERRERO, Luis Fernando. Convenção de arbitragem e processo arbitral. São Paulo: Atlas, 2009.

GUIMARÃES, Flávia Lefévre. A desconsideração da personalidade jurídica no Código de Defesa do Consumidor - Aspectos processuais. São Paulo: Max Limonad. 1998.

HASSON, Felipe; NALIN, Paulo. Existência e validade da cláusula compromissória não escrita: interpretação extensiva do $\operatorname{artigo~} 4^{\circ}, \S 1^{\circ}$, da Lei de Arbitragem, à luz do 
direito brasileiro e comparado. Revista Brasileira de Arbitragem. Volume XIV. Number 55, 2017, p. 11-37.

JUSTEN FILHO, Marçal. Desconsideração da personalidade societária no direito brasileiro. São Paulo: RT, 1987.

LONGA, Daniel Pinheiro. Vinculação das partes não signatárias à cláusula arbitral constante nos acordos de acionistas. Revista de Arbitragem e Mediação. vol. 62 (Jul - Set), 2019, p. 131-156.

MELO, Leonardo de Campos. Extensão da cláusula compromissória e grupos de sociedades na CCI (de acordo com o Regulamento CCI-2012). Revista de Arbitragem e Mediação. Ano 10. Vol 36. Jan-mar, 2013, 255-278.

MOSCHEN, Valesca Raizer Borges; OLIVEIRA, Agatha Brandão de. Os novos paradigmas da arbitragem no âmbito societário: a extensão subjetiva da convenção arbitral. Revista da Faculdade de Direito Milton Campos, v. 24, 2012, p. 349-370.

PRADO, Viviane Muller; DECCACHE, Antonio. Arbitragem e desconsideração da pessoa jurídica. In: CONPEDI. (Org.). Direito Empresarial. XXI Congresso Nacional do CONPEDI/UFF. 1ed.Florianópolis: FUNJAB, 2012, p. 216-245, pp. 236-237. http://www.publicadireito.com.br/artigos/?cod=f5496252609c43eb.

SARAI, Leandro. Disregard doctrine e sua aplicação pela Administração Pública. Revista de Direito Administrativo \& Constitucional. Belo Horizonte: Fórum, 2003, p. 193-219.

STJ, REsp 1698730/SP, Rel. Ministro MARCO AURÉLIO BELLIZZE, TERCEIRA TURMA, julgado em 08/05/2018, DJe 21/05/2018.

TARTUCE, Flávio. A MP 881/19 (liberdade econômica) e as alterações do Código Civil. Primeira parte. Portal Migalhas. Disponível em <https://www.migalhas.com.br/dePeso/16,MI301612,41046-

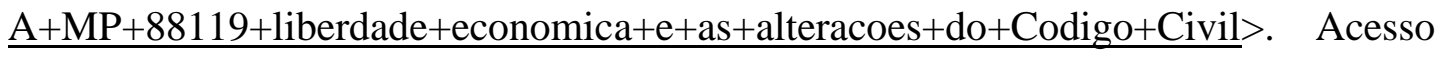
em 10 out. 2019.

WALD, Arnoldo. A desconsideração na arbitragem societária. Revista de Arbitragem e Mediação. vol. 44 (jan - mar) 2015, p. 49 - 64. 
Rio de Janeiro. Ano 15. Volume 22. Número 1. Janeiro a Abril de 2021

Periódico Quadrimestral da Pós-Graduação Stricto Sensu em Direito Processual da UERJ

Patrono: José Carlos Barbosa Moreira (in mem.). ISSN 1982-7636. pp. 488-513

www.redp.uerj.br

WARDE JÚNIOR, Walfrido. Responsabilidade dos sócios. Belo Horizonte: Del Rey, 2007. 